\title{
English Ivy (Hedera helix): Identification and Control of Diseases in Commercial Greenhouse Production and in Landscapes ${ }^{1}$
}

\author{
David J. Norman and G. Shad Ali²
}

\section{Introduction}

In the last few years, English ivy (Hedera helix) has become popular as both an indoor and outdoor ornamental vining plant. English ivy is commonly grown as a potted or container plant, but can also be found in planters and beds in landscapes. One of ivy's prominent characteristics is its dark evergreen leaves and the development of both juvenile and adult foliage. Juvenile ivy plants are often sold as potted plants at retail outlets, while adult plants are used in mature landscapes, as they are easily grown on trellises or made into topiary figures (Chen, McConnell and Everitt 2017). Through selective breeding, hundreds of cultivars have been developed with varying leaf morphology and pigmentation.

English ivy is very disease-resistant, with only a few major diseases causing economic losses in production and in landscape plantings. This EDIS publication will assist commercial ivy growers in identifying and treating various diseases. This publication also will assist residential or commercial property owners in identifying various English ivy diseases.

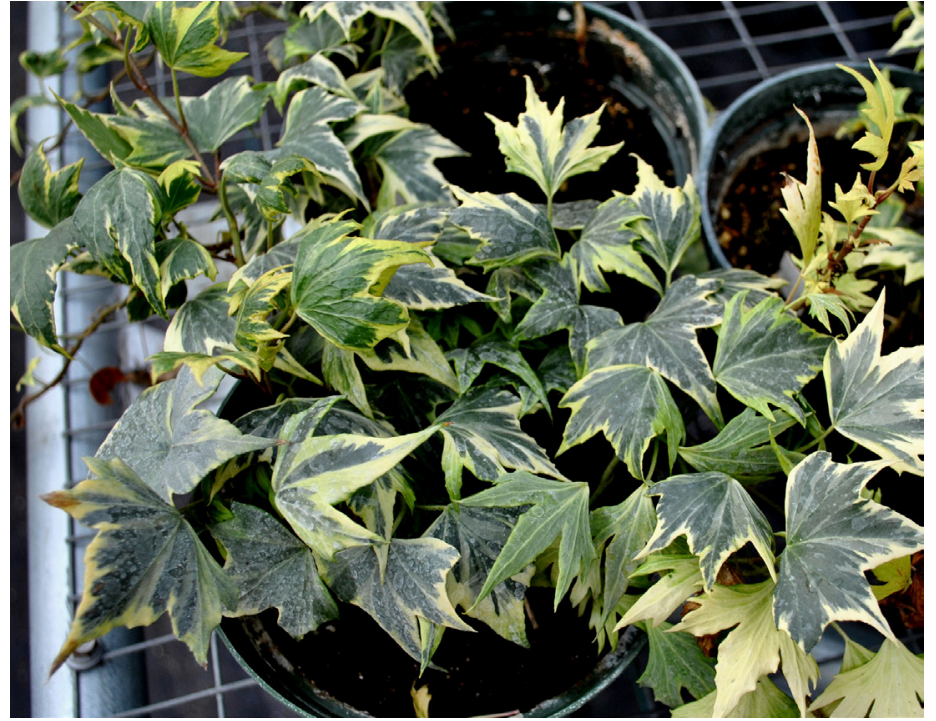

Figure 1. There are many varieties of English ivy varying in leaf morphology and pigmentation.

Credits: Dr. David Norman, UF/IFAS

\section{Bacterial Diseases of English Ivy Bacterial Leaf Spot}

Bacterial leaf spot disease is commonly seen in established landscape plantings and is occasionally seen in the propagation areas in greenhouse production. Because they do not produce spores, bacteria are dependent on outside agents to move from plant to plant, commonly using human contact

1. This document is PP339, one of a series of the Plant Pathology Department, UF/IFAS Extension. Original publication date August 2018. Visit the EDIS website at http://edis.ifas.ufl.edu.

2. David J. Norman, professor; and G. Shad Ali, assistant professor; UF/IFAS Extension, Plant Pathology Department, UF/IFAS Mid-Florida Research and Education Center, Apopka, FL 32703.

The Institute of Food and Agricultural Sciences (IFAS) is an Equal Opportunity Institution authorized to provide research, educational information and other services only to individuals and institutions that function with non-discrimination with respect to race, creed, color, religion, age, disability, sex, sexual orientation, marital status, national origin, political opinions or affiliations. For more information on obtaining other UF/IFAS Extension publications, contact your county's UF/IFAS Extension office. 
or splashing water to spread (Pernezny, Elliott, Palmateer and Havranek 2017).

\section{SYMPTOMS}

Irregular, water-soaked, dark, and necrotic leaf spots are the most common symptoms observed (Figure 2). Watersoaking can be observed by holding the leaves up to the light; you will then see an oily circle surrounding the lesion. Depending on the ivy cultivar and leaf pigmentation, a chlorotic (yellow) halo can be seen surrounding the leaf spot. As lesions age, the centers become papery and may fall out, leaving a "shot gun" appearance to the leaves.

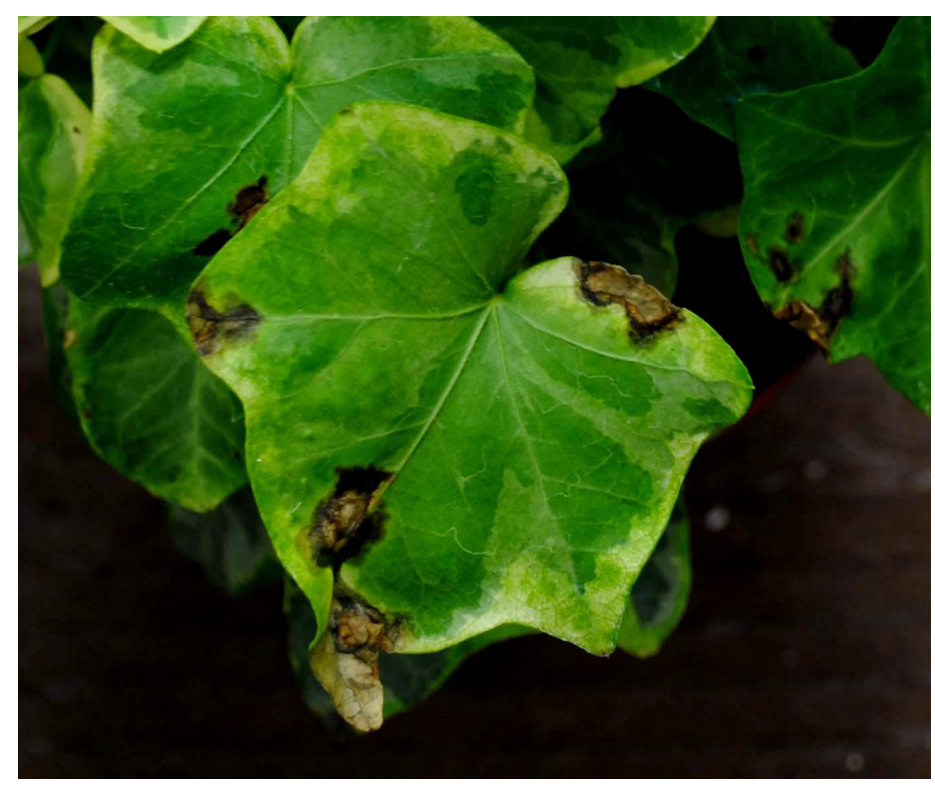

Figure 2. Bacterial leaf spot of English ivy. Note the water soaked oily circles surrounding the lesions.

Credits: Dr. David Norman, UF/IFAS

\section{CAUSAL AGENT}

The bacteria, Xanthomonas campestris pv. hederae, are especially active during warm, humid periods of the year. The bacteria are motile and move through the use of flagella (tails). The bacteria enter the ivy leaves through stomata (pores) and wounds. Once infected, bacterial multiplication and leaf spot formation is rapid. First symptoms appear within 14 days of infection. As bacteria populations increase, bacteria are exuded from the water-soaked leaf spots. These bacteria are transported by splashing to new leaves, thus completing the disease cycle.

\section{CONTROL AND TREATMENT}

Overhead watering is the primary mechanism of bacterial movement and spread. Limiting the length of time that foliage remains wet after irrigation is helpful. One can accomplish this by limiting the number of irrigation cycles and not watering late in the day when there is not sufficient time for the foliage to dry. Eliminating overhead irrigation is usually not possible when establishing ivy cuttings.

In commercial greenhouse production, the disease may be introduced by using contaminated stock for propagation. Using clean, uninfected stock, choosing appropriate pot sizes, and maintaining airflow in the propagation area will help.

Sanitation is important in managing disease outbreaks within greenhouse production and in the landscape. If symptoms are noted early, individual infected leaves can be removed, bagged, and discarded. Leaf removal should never be done when foliage is wet. If wet, the handling will spread the pathogen and make the situation far worse. In this case, it is best to discard the whole plant.

When overhead water cannot be eliminated or the disease cannot be managed through sanitation, applying coppercontaining compounds is the most effective way of combating disease outbreaks. Common products containing copper include $\mathrm{CuPro}^{\mathrm{TM}}$, Phyton $2{ }^{\circledR}$, and Camelot $^{\mathrm{TM}}$. Other products that are useful in suppressing bacterial leaf spot of English ivy include mancozeb (Protect T/ ${ }^{\mathrm{TM}}$, Dithane ${ }^{\circledR}$ ), and $\left(\right.$ Cease $\left.^{\circledR}\right)$. For more information on bactericide selection, please visit the Pesticide Toxicity Profile: CooperBased Pesticides (Fishel 2017).

\section{Fungal Diseases of English Ivy Phytophthora Root and Stem Rot}

Phytophthora root and stem rot disease is seen in landscape settings as well as in greenhouse production. In the landscape, ivy leaves near the base of the plant will exhibit a black necrosis from the leafstalk upward. In greenhouse production of hanging baskets, the symptoms of black necrotic tissue may be seen only on the growing tips. These growing tips are very susceptible to infection (Futch and Graham 2015).

\section{SYMPTOMS}

Infected ivy plants wilt, and there is an abundance of dark black necrotic stem lesions and spots on the foliage (Figure 3). Black necrosis starts at the soil line and progresses toward the growing tip. The initial infection occurs within the root system.

\section{CAUSAL AGENT}

Oomycetes, or water molds, are a group of several hundred organisms, including Phytophthora palmivora, that produce zoospores that are able to swim across the leaf surface. 
These spores are released when there is either rain or irrigation. Irrigation runoff and their ability to swim help facilitate the spread of this pathogen. Zoospores can remain active for hours to days depending on the temperature and moisture.

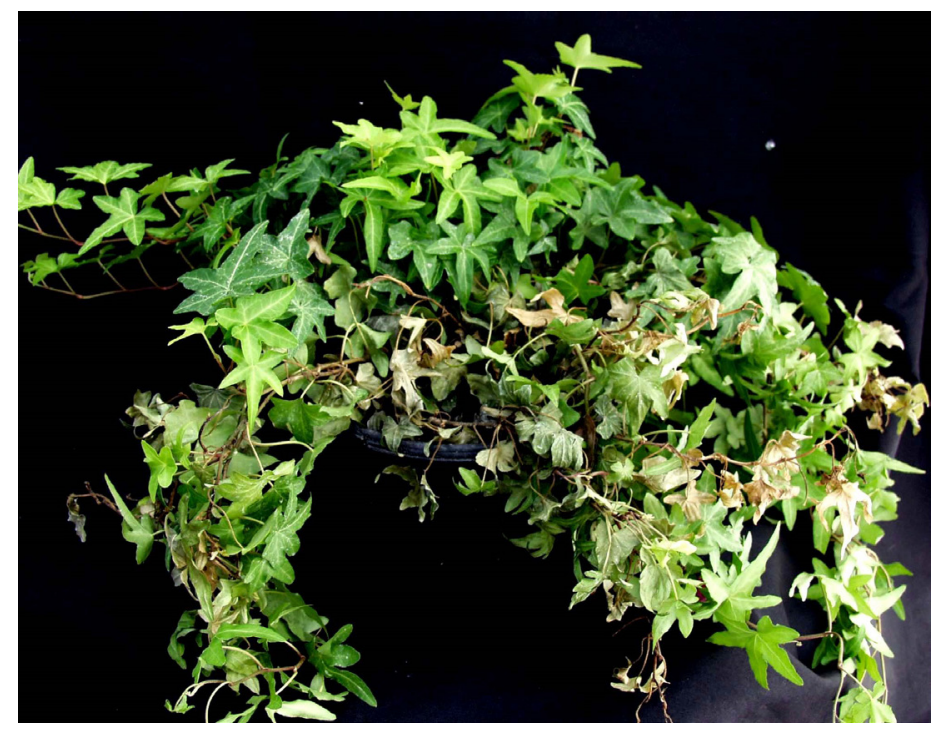

Figure 3. Phytophthora root and stem rot of English ivy. Credits: Dr. David Norman, UF/IFAS

\section{CONTROL AND TREATMENT}

In commercial greenhouse production, exclusion is the best method of controlling this disease. Most outbreaks occur when infected cuttings are purchased and brought into the facility. Disease outbreaks are rare if ivy plants are kept on benches, soilless media is used, and disease-free cutting are obtained. Once introduced into a facility, the disease is hard to control because it is readily moved in water.

Reducing irrigation volumes and frequency will help to control this disease. Ivy plants expressing symptoms should be discarded. Remaining plants will need to be treated with an appropriate fungicide. Registered fungicides, including mefenoxam (Subdue ${ }^{\circledR}$ MAXX $^{\circledR}$ ), aluminum tris/Fosetyl-al (Aliette ${ }^{\circledR}$ WDG), dimethomorph (Stature ${ }^{\circledR}$ ), dimethomorph + ametoctradin $\left(\right.$ Orvego $\left.^{\mathrm{TM}}\right)$, fluopicolide $\left(\right.$ Adorn $\left.^{\mathrm{TM}}\right)$, and phosphorous acid (Alude ${ }^{\mathrm{TM}}, \mathrm{K}-\mathrm{Phite}^{\circledR}, \mathrm{Vital}^{\circledR}$ ), may be used effectively to control Phytophthora palmivora. Rotation of these chemicals is essential for reducing development of fungicide resistance in this pathogen. For more information on fungicide selection, please visit the Homeowner's Guide to Fungicides for Lawn and Landscape Disease Management (Harmon and Palmateer 2014).

\section{Fusarium Root Rot}

Fusarium can be observed in English ivy in both landscape and greenhouse settings when plants begin to wilt and stems may rot off at the soil surface. Often, wind disperses fungal pathogens in the form of spores, which can enter plants through natural openings or wounds (Pernezncy et al. 2017).

\section{IDENTIFICATION}

Fusarium root rot disease is almost identical to symptomology seen with Phytophthora. The key distinguishing characteristic of Fusarium root rot is that English ivy stems at the soil line become covered with a thin layer of white dust-like material. This dust-like material is actually millions of spores, which have formed on the exposed surface of the plant (Figure 4). These spores are easily splashed or blown to nearby plants.

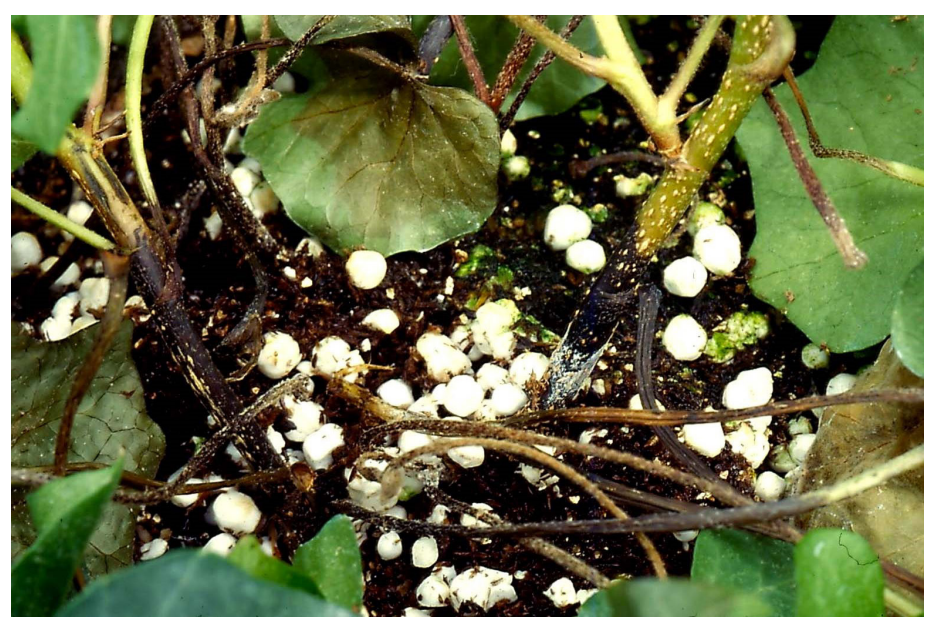

Figure 4. Fusarium root and stem rot of English ivy. Note the white spores on rotten stem.

Credits: Dr. David Norman, UF/IFAS

\section{CAUSAL AGENT}

A fungus, Fusarium oxysporum, which can readily colonize the soil and potting soil mixes, thus contaminating plantings of ivy.

\section{CONTROL AND TREATMENT}

Fusarium oxysporum is a very opportunistic fungus, frequently infecting plants which are already infected with Phytophthora. Diagnostic clinics frequently diagnose Fusarium root rot on English ivy and miss the harder-toisolate and more aggressive Phytophthora. Fungicides that are most effective on Fusarium are not very effective on Phytophthora. Consequently, because of dual infections, fungicide recommendations for Fusarium appear not to work. Sometimes, it is best to treat a Fusarium outbreak with products recommended for Phytophthora, because Phytophthora is probably the pathogen that started the plant's decline. Plants with severe Fusarium infections and abundant spore production on stems should be placed into plastic bags and removed from the production facility. Remaining plants then should be drenched with 
thiophanate-methyl (Clearys $3336^{\mathrm{TM}}$, OHP $6672^{\mathrm{TM}}$ ), fludioxonil (Medallion ${ }^{\circledR}$ ), Azoxystrobin, (Heritage ${ }^{\circledR}$ ), Trifloxystrobin (Compass $\mathrm{O}^{\circledR}$ ), and pyraclostrobin $\left(\right.$ Empress $\left.^{\mathrm{TM}}\right)$. For more information on fungicide selection, please visit the Homeowner's Guide to Fungicides for Lawn and Landscape Disease Management (Harmon and Palmateer 2014).

\section{Rhizoctonia Root Rot and Aerial Blight}

Rhizoctonia root rot can be identified by wilted, matted English ivy leaves on the soil surface in the landscape or in greenhouse production containers. These mats of leaves are often held together by fungal hyphae that can resemble spider webs. Growing tips of vines and roots are very susceptible to infection (Elliot and Harmon 2014).

\section{SYMPTOMS}

English ivy plants will appear wilted. Leaves will look yellowed or chlorotic. Roots and stems will slough off when handled. The symptoms of Rhizoctonia root rot on English ivy are similar to those observed with Phytophthora and Fusarium, as seen in Figure 5, although Rhizoctonia is typically not as common.

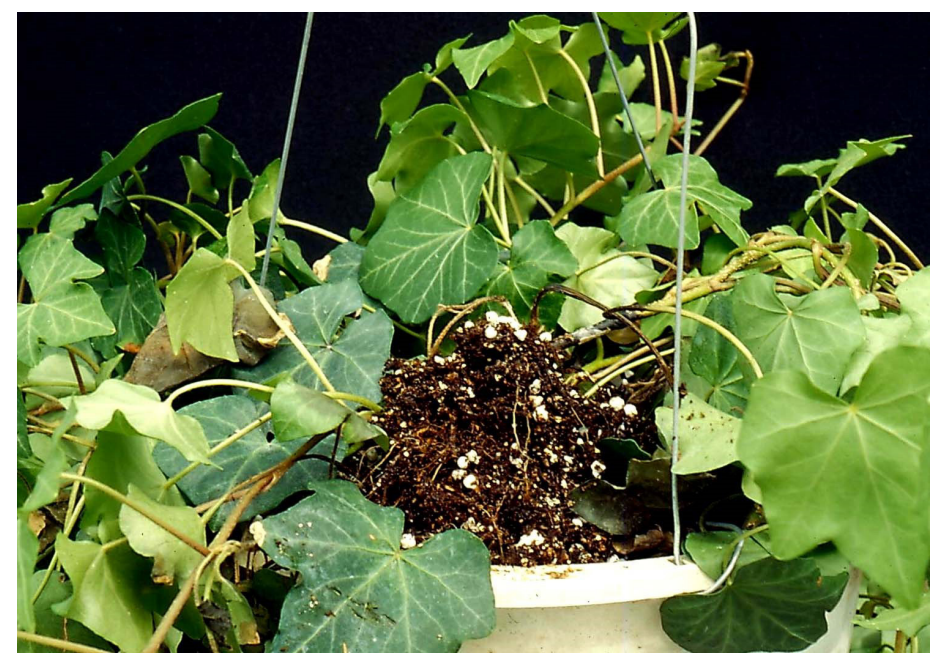

Figure 5. Rhizoctonia root rot of English ivy.

Credits: Dr. David Norman, UF/IFAS

\section{CAUSAL AGENT}

A fungus, Rhizoctonia solani, which colonizes the soil and usually gains access to production facilities via contaminated potting mixes or infected propagation cuttings, is the causal agent. In the landscape, Rhizoctonia can persist in the soil for long periods of time as sclerotia, a weatherresistant hardened compact thatch of the fungus. In the greenhouse, Rhizoctonia may survive as sclerotia and be introduced into the greenhouse in contaminated soil mixes. In warm, wet conditions, the fungus attacks usually through soft growing points such as terminal growth or root tips.

\section{CONTROL AND TREATMENT}

When establishing English ivy into a landscape, take care to clean and thoroughly rake the beds. Remove any dead plant materials from the area, because these may harbor the disease. Monitor irrigation and avoid saturating the landscape. Provide good drainage and good air movement through the growing beds.

Rhizoctonia should not be a problem in ivy greenhouse production if soil mixes are not reused between crops. Avoid mixing native, local soils with commercial potting soils. Ivy plants in greenhouse production should be kept on raised benches well off the soil surface. Ivy cuttings for propagation should be taken from disease-free stock. Highly infected plants should be identified, bagged, and discarded. If the disease cannot be managed through sanitation, applications of triflumizole (Terragard ${ }^{\circledR}$ ) or thiophanate-methyl (Clearys $3336^{\mathrm{TM}}$, OHP $6672^{\mathrm{TM}}$ ) may be effective. For more information on fungicide selection, please visit the Homeowner's Guide to Fungicides for Lawn and Landscape Disease Management (Harmon and Palmateer 2014).

\section{Botrytis Blight}

Botrytis blight is a common disease in greenhouse production facilities and in landscapes when conditions are cool and wet in late fall, winter, and early spring. Botrytis blight presents itself as a grey mold covering leaves and stems (Pernezny et al. 2017).

\section{IDENTIFICATION}

Botrytis infections, also known as grey mold, occur under cool, humid conditions, producing brown to tan lesions on English ivy leaves and stems. These lesions become covered with a characteristic grey-brown fuzz made up of fungal hyphae and spores (Figure 6). Botrytis can readily colonize English ivy tissue, which has been damaged by cold, improper chemical applications, over-fertilization, or rough handling during production or transplanting.

Botrytis blight is a common disease in greenhouse production facilities when temperatures are cooler in the late fall and winter through early spring. This pathogen is frequently found on old or damaged leaves after an extended shipping period where cool, humid conditions persist. In the landscape, Botrytis can survive on old, dead leaves at the base of plants. Spores that are produced on this thatch can spread and infect tender growing points of English ivy when cool, wet conditions occur. Botrytis cinereal, a fungus, is the causal agent for this disease. 


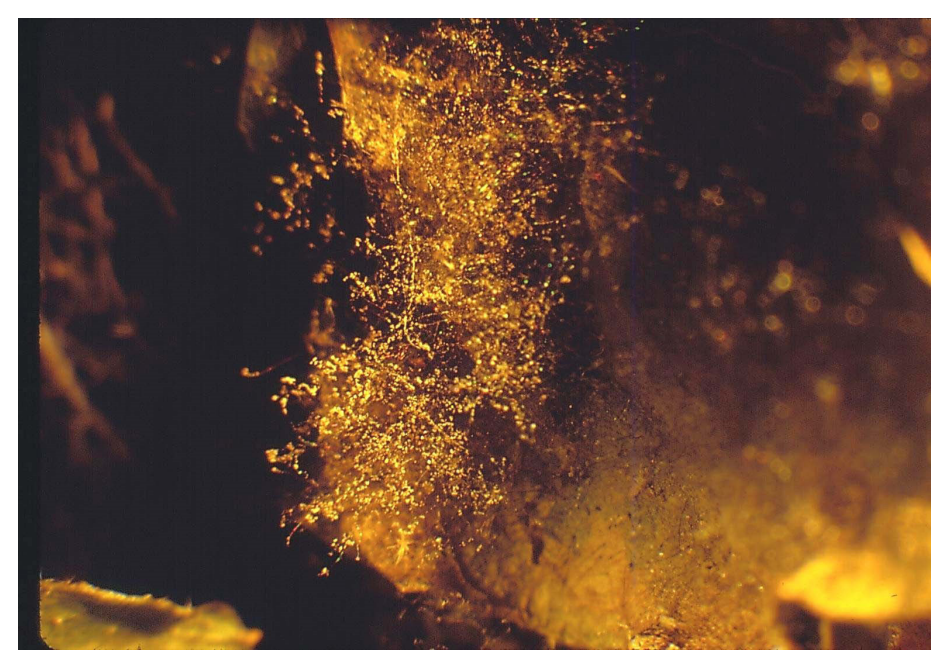

Figure 6. Botrytis blight of English ivy. Note the grey-brown fuzz made up of spores and fungal hyphae.

Credits: Dr. Dave Norman, UF/IFAS

\section{CONTROL AND TREATMENT}

Lowering the humidity in the greenhouse is important for disease control. In the landscape, reduce irrigation volumes. Avoid overfertilization, which might damage leaf and vine tissue and provide entry wounds for infections. Plants that are heavily damaged should be removed in order to lower inoculum concentrations.

Registered fungicides that aid in the control of Botrytis blight are fenhexamid (Decree ${ }^{\circledR}$ ) and iprodione (Chipco ${ }^{\circledR}$ 26019). For more information on fungicide selection, please visit the Homeowner's Guide to Fungicides for Lawn and Landscape Disease Management (Harmon and Palmateer 2014).

\section{Colletotrichum Leaf Spot}

Colletotrichum leaf spot occurs on English ivy in outdoor landscape settings. High humidity in commercial shadehouse production facilities is also conducive to this disease development (Dicklow 2013).

\section{IDENTIFICATION \& SYMPTOMS}

Small light-brown leaf spots are the first symptom of Colletotrichum leaf spot on English ivy. As the disease progresses, they enlarge and become dark brown (Figure 7). As these lesions age, small, dark structures form on the lesion surfaces, many times in concentric rings. These structures are referred to as acervuli, and within each acervuli, thousands of spores are produced (Figure 8). These spores are easily spread from plant to plant via water and wind movement. Colletotrichum trichellum, a fungus, is the causal agent for this disease.

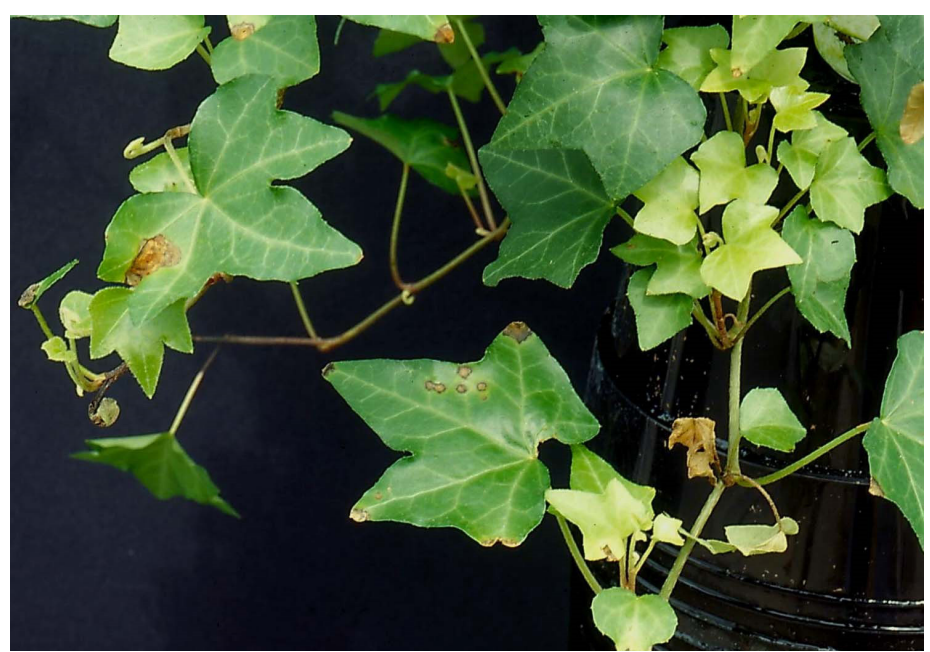

Figure 7. Colletotrichum leaf spot of English ivy. Credits: Dr. Dave Norman, UF/IFAS

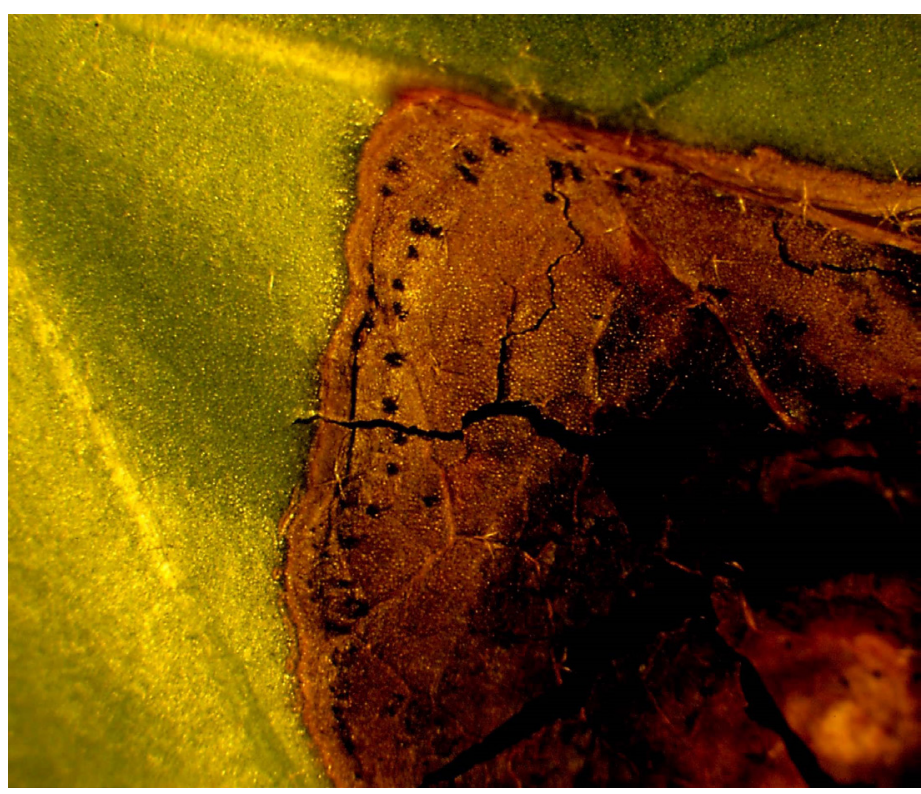

Figure 8. Colletotrichum acervuli on edge of leaf spot. Credits: Dr. Dave Norman, UF/IFAS

\section{CONTROL AND TREATMENT}

High humidity is conducive to disease development; therefore, lowering humidity in the production facility or reducing irrigation volumes in the landscape will aid in disease control. Planting under covered structures and using drip irrigation substantially helps.

English ivy leaves with lesions should be clipped and placed in plastic bags to limit spore movement and subsequently removed from the nursery or landscape. Spores also can be easily transported on clothing, so clean or change clothing before moving to a different greenhouse.

If chemical treatments are needed to supplement sanitation, copper oxychloride and copper sulfate are effective in Colletotrichum control, as are mancozeb (Dithane ${ }^{\circledR}$, Manzate $^{\circledR}$ ) and iprodione (Chipco ${ }^{\circledR}$ 26019). For more information on 
fungicide selection, please visit the Homeowner's Guide to Fungicides for Lawn and Landscape Disease Management (Harmon and Palmateer 2014).

\section{References}

Chen, J., D. B. McConnell, and K. C. Everitt. 2017. Cultural Guidelines for Commercial Production of Interiorscape Hedera. ENH990. Gainesville: University of Florida Institute of Food and Agricultural Sciences. http://edis.ifas. ufl.edu/ep243

Dicklow, M. B. 2013. "Leaf Spot Diseases of Floricultural Crops.” http://ag.umass.edu/greenhouse-floriculture/ fact-sheets/leaf-spot-diseases-of-floricultural-crops

Elliott, M. L. 2017. Large Patch. SS-PLP-5. Gainesville: University of Florida Institute of Food and Agricultural Sciences. http://edis.ifas.ufl.edu/lh044

Fishel, F. M. 2017. Pesticide Toxicity Profile: Cooper-Based Pesticides. PI-66. Gainesville: University of Florida Institute of Food and Agricultural Sciences. http://edis.ifas.ufl.edu/ pi013

Futch, S. H. and J. H. Graham. 2015. Field Diagnosis and Management of Phytophthora Diseases. HS-1015. Gainesville: University of Florida Institute of Food and Agricultural Sciences. http://edis.ifas.ufl.edu/hs261

Harmon, P. and A. Palmateer. 2014. Homeowner's Guide to Fungicides for Lawn and Landscape Disease Management. PP-233. Gainesville: University of Florida Institute of Food and Agricultural Sciences. http://edis.ifas.ufl.edu/pp154

Pernezny, K., M. Elliot, A. Palmateer, and N. Havranek. 2017. Guidelines for Identification and Management of Plant Disease Problems: Part II. Diagnosing Plant Disease Caused by Fungi, Bacteria and Viruses. PP249. Gainesville: Institute of Food and Agricultural Sciences. http://edis.ifas.ufl.edu/ mg442 